\title{
SELECTED LIFE HISTORY TRAITS \\ OF LEPTAXIS SIMIA (GASTROPODA: HYGROMIIDAE) ESTABLISHED IN THE LABORATORY
}

\author{
Elżbieta Kuźnik-Kowalska ${ }^{1}$, Robert A. D. Cameron ${ }^{2,3}$ and Mągorzata Proćków ${ }^{4}$ \\ ${ }^{1}$ Department of Invertebrate Systematics and Ecology, Institute of Environmental Biology, \\ Wroctaw University of Environmental and Life Sciences \\ Kożuchowska 5b, 51-631 Wrocław, Poland; corresponding author \\ E-mail: elzbieta.kowalska@upwr.edu.pl; https://orcid.org/0000-0002-5509-0336 \\ ${ }^{2}$ Department of Animal and Plant Sciences, University of Sheffield \\ Sheffield S10 2TN, United Kingdom \\ ${ }^{3}$ Department of Zoology, Natural History Museum, London SW7 5BD, United Kingdom \\ E-mail:r.cameron@sheffield.ac.uk \\ ${ }^{4}$ Museum of Natural History, University of Wroctaw \\ ul. Sienkiewicza 21, 50-335 Wrocław, Poland \\ E-mail: malgorzata.prockow@uwr.edu.pl; https://orcid.org/0000-0003-2240-7306
}

\begin{abstract}
Among ten adult specimens of the Madeiran endemic land snail Leptaxis simia (Férussac, 1832) (Gastropoda: Hygromiidae), harvested from their natural environment, kept in the laboratory, a single clutch of 110 eggs was reared, and the mortality, growth and reproductive capacity of hatchlings over a 1240-day period were monitored. Of 70 hatchlings, 34 survived to complete shell growth at around 640 days. Growth was rapid, and mortality high in the early stages; growth slowed, and mortality was very low as the full size was approached. Snails kept singly failed to lay any eggs. Among those with potential mates, only three clutches were produced, one of which yielded no hatchlings. Clutches were produced at least five months after shell growth was complete. Mortality increased sharply after the onset of sexual maturity, and the oldest snail survived for three and a half years. The apparently very strictly semelparous mode of reproduction, delayed sexual maturity and a relatively long period of juvenile growth are discussed in relation to other species and to the practical problems of rearing potentially endangered species in captivity.
\end{abstract}

Key words: endemic, delayed maturity, growth rate, reproduction, life history traits, Leptaxis simia, Gastropoda, Hygromiidae.

\section{INTRODUCTION}

In common with many oceanic islands, the Madeiran archipelago has a rich fauna of endemic land snails (СоOK 1996, CAMEron et al. 2013, TrianTIs et al. 2016). Many are restricted to single islands and have limited ranges within them. Human disturbance in the form of habitat destruction, introduced predators, and competitors have caused many extinctions (LYDEARD et al. 2004, Nicolai \& ANSART 2017); many others are listed as Critically Endangered (Neubert et al. 2019, IUCN 2021). The effects of climate change are expected to add to the threats already identified. 
The capacity to maintain viable populations is at least partly related to patterns of life history and reproductive capacity. Unfortunately, even among continental faunas, details of such features are available for only a minority of species (Kuźnik-Kowalska 1999, Maltz 2003). Data for island endemics are even less abundant (CowIE 1996), despite the need for information to assist in conservation measures. Such data may also shed light on the evolutionary consequences of isolation on islands (CAMERon 2016).

Among the many endemic species of land snail found only in the Madeiran archipelago, and the Azores are those in the helicoid genus Leptaxis Lowe, 1852 (Bank et al. 2002). Among these is Leptaxis simia (Férussac, 1832), previously assigned to L. erubescens (Lowe, 1831).

It is native to Madeira, Porto Santo and Desertas, where it is relatively common, although never found in abundance (SEDdon \& Martins 2011). Most often, it is found in partly open habitats with bushy or shrubby vegetation rather than in forests or very exposed sites (CAMERoN \& CooK 1997). In the Azores, it is regarded as introduced (BAcкHUYs 1975). It is rare and usually confined to semi-open and anthropogenic sites (Morelet \& DrouËT 1857, Cameron et al. 2007). A medium-sized snail (shell width of $12-13 \mathrm{~mm}$ and height of 10-11 mm), it is clearly distinct from other species (Koene \& MurATov 2004). While not currently threatened, it can serve as an example of an endemic, oceanic island species. In the present paper, we aimed at determining some data on the reproduction of L. simia in laboratory conditions.

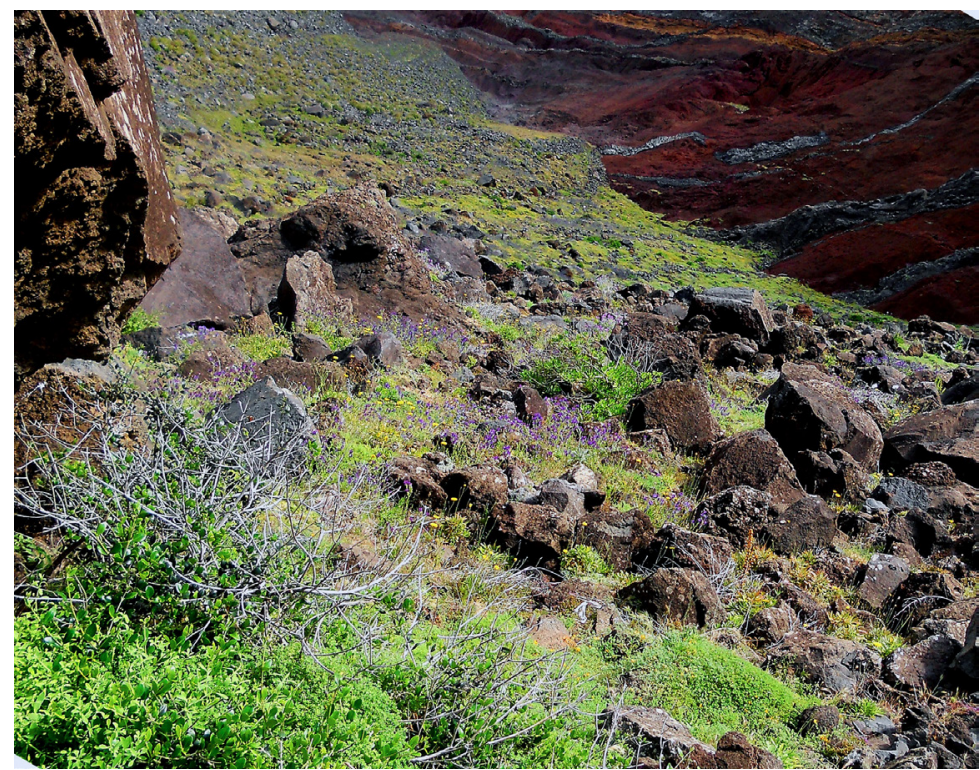

Fig. 1. Sample site of L. simia on Deserta Grande 
Table 1. The number of snails in boxes from the $F_{1}$ generation. Each box 1-20 contained a single snail.

\begin{tabular}{ccc}
\hline $\begin{array}{c}\text { Box } \\
\text { no. }\end{array}$ & $\begin{array}{c}\text { At start of } \\
\text { experiment }\end{array}$ & $\begin{array}{c}\text { At 637 days } \\
\text { of age }\end{array}$ \\
\hline $1-20$ & No. of snails & (mortality in \%) \\
21 & 5 & $3(40)$ \\
22 & 5 & $3(40)$ \\
23 & 5 & $2(60)$ \\
24 & 10 & $2(80)$ \\
25 & 10 & $2(80)$ \\
26 & 5 & $2(60)$ \\
27 & 2 & $1^{*}(50)$ \\
28 & 2 & $2(0)$ \\
29 & 2 & $1^{*}(50)$ \\
30 & 2 & $2(0)$ \\
31 & 2 & $2(0)$ \\
\hline
\end{tabular}

${ }^{*}$ As the snails in these boxes died within the first two months, they were classified as being singly kept in terms of possible mating

Table 2. Combination of selected snails on day 849 .

\begin{tabular}{cccc}
\hline Box no. & $\begin{array}{c}\text { No. of in- } \\
\text { dividuals }\end{array}$ & $\begin{array}{c}\text { New box } \\
\text { number }\end{array}$ & $\begin{array}{c}\text { No. of in- } \\
\text { dividuals }\end{array}$ \\
\hline 2 & 1 & 32 & 2 \\
13 & 1 & & \\
21 & 3 & 33 & 7 \\
24 & 2 & & \\
25 & 2 & & \\
23 & 2 & 34 & 4 \\
31 & 2 & & \\
26 & 2 & 35 & 4 \\
28 & 2 & & \\
\hline
\end{tabular}

*But on day 909 (when the eggs were laid) there were three individuals

\section{MATERIAL AND METHODS}

Ten adult $L$. simia were collected in July 2012 from a population on Deserta

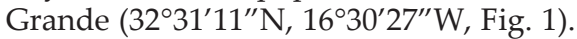
The snails were kept in three boxes (with six in one (box size: $15.5 \times 12.5 \times 7 \mathrm{~cm}$ ) and two in each of the others $(11.5 \times 7 \times 7 \mathrm{~cm}))$ in a climate chamber of constant temperature $\left(22^{\circ} \mathrm{C}\right.$ day, $15^{\circ} \mathrm{C}$ night), relative humidity of $80 \%$ and $12: 12$ photoperiod (thus approximating average natural conditions of temperature and daylight). A single clutch of 110 eggs was laid on 7th December 2012 in the box of six snails, five of which remained alive at the time. The clutch was initially kept in Petri dishes lined with damp tissue paper and soil. 70 eggs hatched successfully (64\%). These were then distributed in boxes as follows: 20 kept singly (box size: $6 \times 7.5 \times 5 \mathrm{~cm}$ ), 5 pairs $(11.5 \times 7 \times 7 \mathrm{~cm}), 4$ groups of 5 individuals $(15.5 \times 12.5 \times 5 \mathrm{~cm})$ and 2 groups of 10 individuals $(15.5 \times 12.5 \times 7 \mathrm{~cm})$ (Table 1) and were kept in a climate chamber under the conditions as above. All the bottoms of the containers were covered with tissue paper and moist soil $(2-2.5 \mathrm{~cm}$ deep in $1 / 2$ of the container) to encourage egg-laying. Dolomite tablets were served as a supplementary source of calcium. Food (e.g. lettuce, carrot) was provided as required. In addition, the snails were sprayed with boiled, cooled water once a week.

The boxes were inspected regularly, and mortality was recorded. The growth of individuals was assessed by counting whorls at 30-day intervals using EHrmann's method (1933). Although adult status (the completion of the lip at the shell-mouth) was achieved earlier (see below), no eggs had been laid after 849 days. Snails from some boxes were then combined (Table 2). From two of these boxes, and only these, three clutches were laid. 


\section{RESULTS}

Of the initial 70 snails reared from the original clutch, 34 survived for more than 637 days, the time at which the first snail achieved adulthood (lip formation completed by snails with 4.8-5.2 whorls) (Fig. 2). Mortality was heavy in the first six months of life, very low thereafter until the approxi-

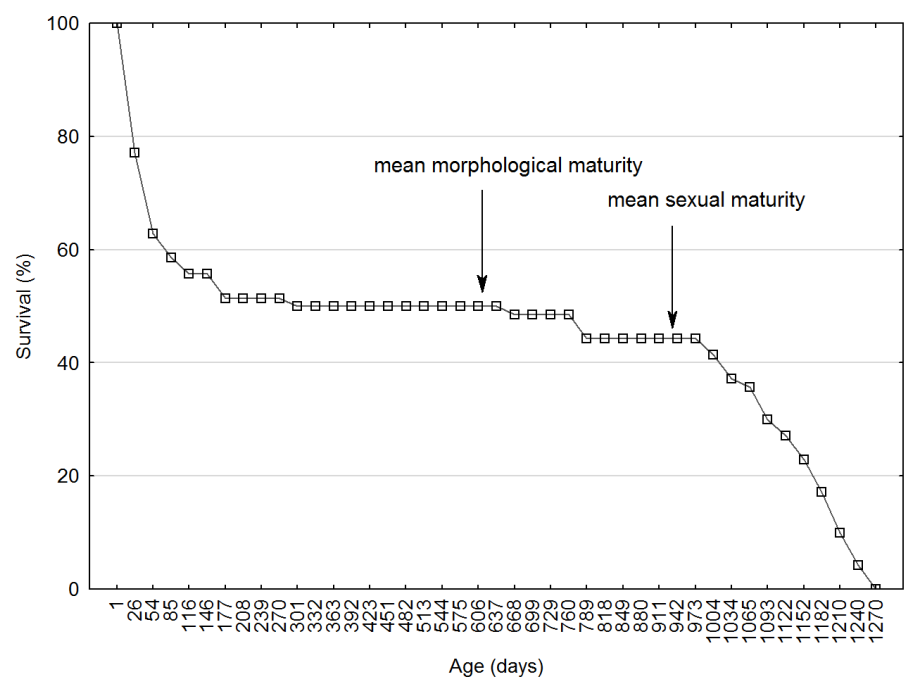

Fig. 2. Survivorship curve of $L$. simia individuals $(n=70)$; morphological maturity $=$ lip formation, sexual maturity $=$ first egg lying

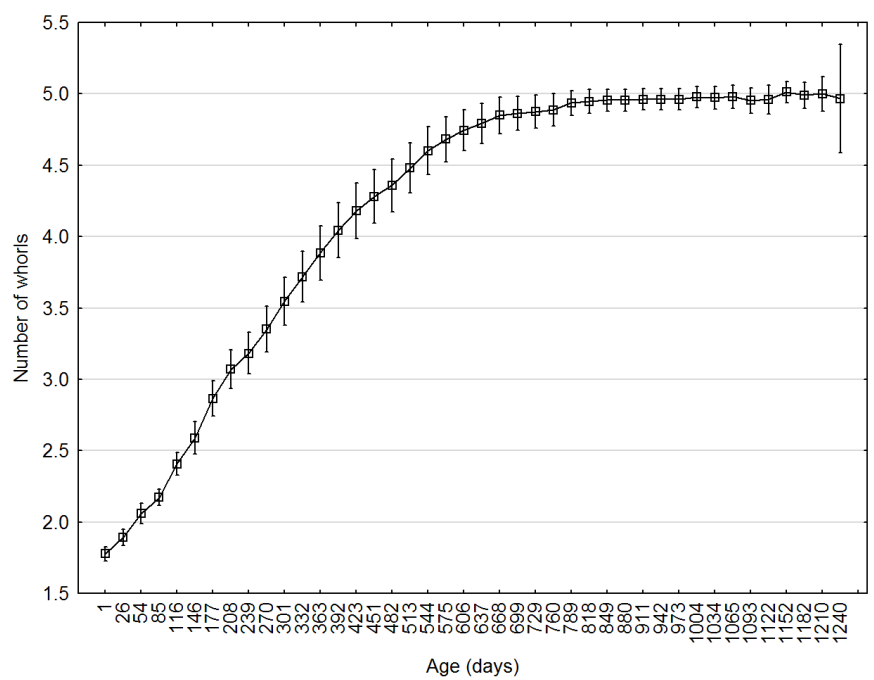

Fig. 3. Growth pattern of L. simia individuals $(n=34)$. The error bars represent $95 \%$ confidence intervals 
Table 3. Reproduction in Leptaxis simia. Data from the original clutch (P) added for comparison. age - days and no. of whorls when laying eggs; incubation time - mean, range [days] and (SD); $n-$ no. of individuals kept in box; viability $=$ hatching success .

\begin{tabular}{cccccccc}
\hline & Box no. & $n$ & No. clutches & Age & No. eggs & Incubation time & Viability (\%) \\
\hline $\mathrm{P}$ & $\mathrm{I}$ & 5 & 1 & $\begin{array}{c}\text { no data } \\
5.0-5.2\end{array}$ & 110 & 16.4 & 63.6 \\
& & & 913 & 90 & $12-21(2.1)$ & \\
\hline $\mathrm{F}_{1}$ & 34 & 4 & 2 & $4.8-5.1$ & & $11-17(1.3)$ & 46.7 \\
& & & 931 & 44 & - & 0 \\
& & & & $4.8-5.1$ & & & \\
& & & & 909 & 22 & 13.9 & 81.8 \\
& & & & 5.2 & & $11-16(1.5)$ & \\
\hline
\end{tabular}

mate date of sexual maturity. It then increased rapidly, the last survivor dying three and a half years after hatching. The juvenile mortality was greatest in the boxes containing 10 snails ( $80 \%$ ), whereas only $60-40 \%$ in the others.
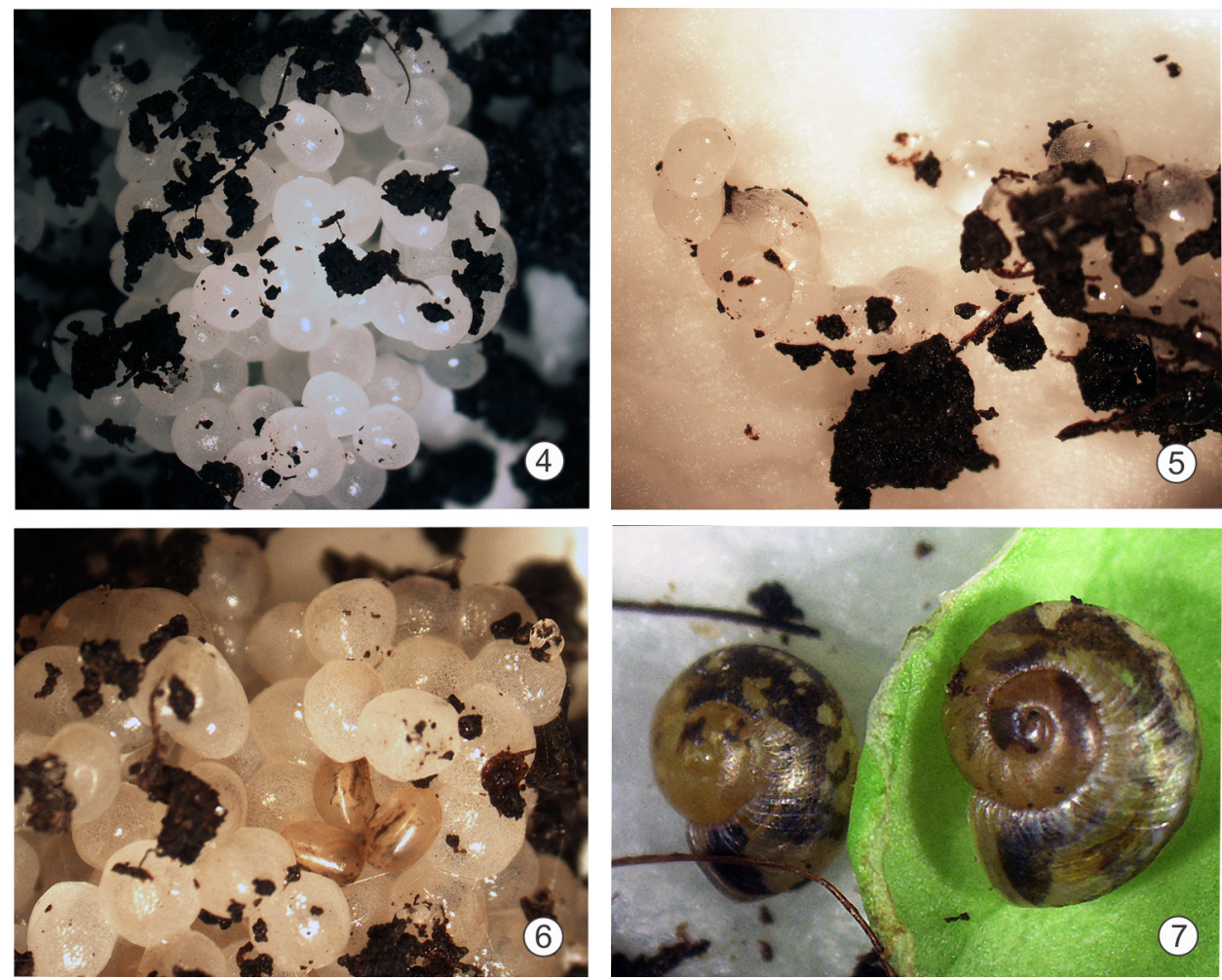

Figs 4-7. Freshly laid eggs of L. simia (4), non-hatched eggs (5), juveniles during asynchronous hatching (6), and three-month snails (7) 
Growth rates varied greatly, especially among those that died before reaching adult status. For those that did become adult, the growth rate was more consistent. It was rapid at first (Fig. 3) but slowed down greatly after most approached adulthood after about 600 days. Numbers in each box did not have any significant influence on the growth rate.

Three clutches were laid among snails from two boxes, both containing snails transferred from more than one box after reaching maturity (Table 3). Leaving aside those snails that remained single, these three clutches derive from a total of 20 snails that survived to adulthood with potential partners $(15 \%)$. One, with rather more elliptical eggs, failed to produce any hatchlings. Clutches were laid at least 250 days after the nominal adult status was achieved, and hatching was asynchronous (Figs 4-7).

\section{DISCUSSION}

This study was carried out as an exploratory venture into captive breeding of island endemic snails. Its small scale and the fact that clutches laid by the progeny of the original parent are the result of sibling crosses makes conclusions tentative, as does the constant, aseasonal conditions in which the snails were kept. Nevertheless, it reveals aspects of the life history of L. simia that may add to both comparative studies of reproductive strategies and to the development of appropriate conservation actions.

On the evidence available, L. simia does not self-fertilise, or does so only very rarely, as is the case among helicoid snails generally (Lucarz 1991, CHEN 1994, Lush 2007, Kuźnik-Kowalska et al. 2013a). The clutch sizes found here (22-110 eggs, mean 67) are rather larger than those recorded for most other Hygromiidae (Kuźnik-Kowalska \& RoKsela 2009, ProćKów \& KuźNik-KowalsKa 2016), but are similar to those recorded for Monacha (TAYLOR 1916). Likewise, they are within the range recorded in the generally larger Helicidae (Heller 2001, Kramarenko 2013, Cameron 2016). Hatching success varied greatly, but the failure rate is within the range recorded for other species (ToмpA 1984).

L. simia appears to be very strictly semelparous, death following some months after a single clutch has been laid (Hughes \& Simons 2014). While many other land snails and slugs are also limited to reproduction in one season only, rather few are restricted to a single clutch within it; rather, egglaying may be spread over breeding seasons of varying length as in Trochulus hispidus (Proćków et al. 2013) or Monacha cantiana (Chatfield 1968). There are many others (Riedel \& Wiktor 1974, WiкTor 1989). While the two-year period taken to reach adult size is unusual in semelparous snails, it has been found in others, where, however, it may vary with climate or population density (Heller 2001). Size appears to have little to do with the length of time taken to reach maturity (Heller et al. 1997, PoKryszKo 2001). Intraspe- 
cific variation in growth rate may lengthen attaining maturity until the next reproductive season even within the same population or in populations from different geographic regions (e.g. Cowie 1984, Staikou \& Lazaridou-Dimitriadou 1990, Avivi \& Arad 1993, Kuźnik-Kowalska et al. 2013b, ProćKów \& KuŹnik-Kowalska 2016, Marzec et al. 2020). The remarkable uniformity of growth rate found in our $L$. simia reaching adulthood might not be reflected in natural populations.

L. simia in our laboratory showed one other feature atypical of semelparous species: the period of several months elapsing between the completion of growth and the start of reproduction. In many species, semelparous or iteroparous, sexual maturity is either coincident with the completion of growth or may, indeed, precede it, as in T. pisana (CowIE 1984) or Lissachatina fulica (Tоміу ама 1993). Delay in reproductive activity is more normally associated with long-lived species such as the mainly iteroparous Clausiliidae (GrokAs \& Mylonas 2002, Maltz \& Sulikowska-Drozd 2008, 2011). It is also recorded in the helicid Cepaea nemoralis (Williamson 1975, cited in Cameron 2016). Unlike these species and others such as Vertiginidae, however, there is no spurt in growth just before adult size, and shell lips and teeth are developed (CAMERON 2016). For long-lived species, investment in adult shell features prior to reproduction is presumed to strike a balance between the risk of predation and speed of reproduction; it is unexplained here, and further work would be needed to relate the phenomenon to gonadal development.

In terms of the rearing of snails in captivity, the high initial mortality of juveniles is comparable to that found in many studies of natural populations. Interestingly, the remarkably low mortality among those L. simia that reached adult size until they had passed a presumed state of sexual maturity, is coupled with the very poor rate of reproductive success. A simultaneous attempt was made, in the same laboratory, to induce breeding in the much more endangered Atlantica calathoides (R. T. Lowe, 1863) from the same island; adult snails survived for several years but did not lay eggs. It seems that establishing the conditions suitable for breeding is a harder task than for those that sustain survival.

Acknowledgements - We would like to thank the reviewers for their helpful comments and corrections.

\section{REFERENCES}

Avivi, T. R. \& Arad, Z. (1993): Population dynamics of the snail Theba pisana (Helicidae) in the sand dunes of northern Israel. - Israel Journal of Zoology 39: 245-254. https://doi.org/10.1080/00212210.1993.10688716 
BAскнUYs, W. (1975): Zoogeography and taxonomy of the land and freshwater molluscs of the Azores. - Backhuys \& Meesters, Amsterdam, XII + 350 pp., XXXII pls.

Bank, R. A., Groh, K. \& Ripken, T. E. J. (2002): Catalogue and bibliography of the nonmarine Mollusca of Macaronesia. Pp. 89-235, pls 14-26. In: Falkner, M., GroH, K. \& Speight, M. C. D. (eds): Collectanea Malacologica. Festschrift für Gerhard Falkner. ConchBooks \& Friedrich-Held-Gesellschaft, Hackenheim, München.

Cameron, R. A. D. (2016): Slugs and snails. Collins New Naturalist Library, Book 133. - HarperCollins Publishers, London, 528 pp.

Cameron, R. A. D. \& Cook, L. M. (1997): Forest and scrub snail faunas from northern Madeira. - Malacologia 39: 29-38.

Cameron, R. A. D., Da Cunha, R. M. T. \& Martins, A. F. (2007): Chance and necessity: land-snail faunas of São Miguel, Azores, compared with those of Madeira. - Journal of Molluscan Studies 73: 11-21. https://doi.org/10.1093/mollus/eyl027

Cameron, R. A. D., Triantis, K. A., Parent, C. E., Gullhaumon, F., Alonso, M. F., Ibáñez, M., Martins, A. M. F., Ladle, R. J. \& Whittaker, R. J. (2013): Snails on oceanic islands: testing the general dynamic model of oceanic island biogeography using linear mixed effect models. - Journal of Biogeography 40: 117-130. https://doi.org/10.1111/j.1365-2699.2012.02781.x

Chatfield, J. E. (1968): The life history of the helicid snail Monacha cantiana (Montagu), with references also to M. cartusiana (Müller). - Proceedings of the Malacological Society of London 38: 233-245.

Chen, X. (1994): Self-fertilization and cross-fertilization in the landsnail Arianta arbustorum (Mollusca, Pulmonata: Helicidae). - Journal of Zoology 232: 465-471.

Соок, L. M. (1996): Habitat, isolation and the evolution of Madeiran land snails. - Biological Journal of the Linnean Society 59: 457-470. https://doi.org/10.1111/j.1095-8312.1996.tb01477.x

Cowie, R. H. (1984): The life-history and productivity of the land snail Theba pisana (Mollusca: Helicidae). - Journal of Animal Ecology 53: 311-325. https://doi.org/10.2307/4359

Cowie, R. H. (1996): Pacific island land snails: relationships, origins and determinants of diversity. Pp. 347-372. In: Keast, A. \& Miller, S. E. (eds): The origin and evolution of Pacific Island biotas, New Guinea to eastern Polynesia: patterns and processes. - SPB Academic Publishing, Amsterdam.

Ehrmann, P. (1933): Mollusken (Weichtiere). Pp. 1-264. In: Brohmer, P., Ehrmann, P. \& Ulmer, G. (eds): Die Tierwelt Mitteleuropas. Vol 2. - Quelle \& Meyer, Leipzig.

Grokas, S. \& Mylonas, M. (2002): Spatial distribution, density and life history in four Albinaria species (Gastropoda, Pulmonata, Clausiliidae). - Malacologia 44: 33-46.

Heller, J. (2001): Life history strategies. Pp. 413-445. In: BArker, G. M. (ed.): The biology of terrestrial molluscs. - CAB International, Oxford. https://doi.org/10.1079/9780851993188.0413

Heller, J., Sivan, N. \& Hodgson, A. N. (1997): Reproductive biology and population dynamics of an ovoviviparous land snail Lauria cylindracea (Pupillidae). - Journal of Zoology 243: 263-280. https://doi.org/10.1111/j.1469-7998.1997.tb02781.x

Hughes, P. W. \& Simons, A. M. (2014): The continuum between semelparity and iteroparity: plastic expression of parity in response to season length manipulation in Lobelia inflata. - BMC Ecology and Evolution 14: 90. https://doi.org/10.1186/1471-2148-14-90

IUCN (2021): The IUCN Red list of threatened species. Version 2021-1. - https://www.iucnredlist.org [Downloaded on 20.04.2021] 
Koene, J. M. \& Muratov, I. V. (2004): Revision of the reproductive morphology of three Leptaxis species (Gastropoda, Pulmonata, Hygromiidae) and its implication on dart evolution. - Malacologia 46: 73-78.

Kramarenko, S. S. (2013): The analysis of the reproductive traits of the pulmonate molluscs: a mini-review. - Ruthenica 23: 115-125.

KUŹNIK-KowALSKA, E. (1999): Life cycle and population dynamics of Discus rotundatus (O. F. Müller, 1774) (Gastropoda: Pulmonata: Endodontidae). - Folia Malacologica 7: 5-17. https://doi.org/10.12657/folmal.007.001

Kuźnik-Kowalska, E., Lewandowska, M., Pokryszko, B. M. \& Proćкów, M. (2013a): Reproduction, growth and circadian activity of Bradybaena fruticum (O. F. Müller, 1774) (Gastropoda: Pulmonata: Bradybaenidae) in the laboratory. - Central European Journal of Biology 8: 693-700. http://dx.doi.org/10.2478/s11535-013-0182-5

Kuźnik-Kowalska, E., Рокryszko, B. M., Рroćкów, M. \& Oczkowska, M. (2013b): On the population dynamics, reproductive biology and growth of Succinea putris (Linnaeus, 1758) (Gastropoda: Pulmonata: Succineidae). - Folia Malacologica 21: 215-224. https://doi.org/10.12657/folmal.021.024

Kuźnik-Kowalska, E. \& Roksela, A. (2009): Life cycle of Perforatella bidentata (Gmelin, 1791) (Gastropoda: Pulmonata: Helicidae). - Folia Malacologica 17: 199-214. http://dx.doi.org/10.2478/v10125-009-0016-x

Lucarz, A. (1991): Evidence of an egg-laying factor in the prostatic secretions of Helix aspersa Müller. - Comparative Biochemistry and Physiology Part A: Physiology 100: 839843. https://doi.org/10.1016/0300-9629(91)90301-R

Lush, A. (2007): Biology and ecology of introduced snail Microxeromagna armillata in south eastern Australia. - Ph.D. thesis, University of Adelaide, Adelaide.

Lydeard, C., Cowie, R. H., Ponder, W. F., Bogan, A. E., Bouchet, P., Clark, S. A., Cummings, K. S., Frest, T., Gargominy, O., Herbert, D. G., Hershler, R., Perez, K. E., Roth, B., Seddon, M., Strong, E. E. \& Thompson, F. G. (2004): The global decline of nonmarine mollusks. - BioScience 54: 231-330. https://doi.org/10.1641/0006-3568(2004)054[0321:TGDONM]2.0.CO;2

Maltz, T. K. (2003): Life cycle and population dynamics of Helicodonta obvoluta (O. F. Müller, 1774) (Gastropoda: Pulmonata: Helicidae). - Folia Malacologica 11: 63-88. https://doi.org/10.12657/folmal.011.008

Maltz, T. K. \& Sulikowska-Drozd, A. (2008): Life cycles of clausiliids of Poland-knowns and unknowns. - Annales Zoologici 58: 857-880. https://doi.org/10.3161/000345408X396783

Maltz, T. K. \& Sulikowska-Drozd, A. (2011): Delayed maturation in the genus Vestia P. Hesse (Gastropoda: Pulmonata: Clausiliidae): a model for clausiliid lifecycle strategy. - Journal of Molluscan Studies 77: 41-53. https://doi.org/10.1093/mollus/eyq040

Marzec, M., Kuźnik-Kowalska, E. \& Proćków, M. (2020): Shell morphology, growth pattern and population dynamics of the land snail Xerolenta obvia (Menke, 1828) in two areas of different climatic conditions within a temperate climate region. - Acta Zoologica Academiae Scientiarum Hungaricae 66: 69-84.

https://doi.org/10.17109/AZH.66.1.69.2020

Morelet, A. \& DrouËt, H. (1857): Conchologiae Azoricae prodromus novarum specierum diagnoses sistens. - Journal de Conchyliologie 6: 148-153.

Neubert, E., Seddon, M. B., Allen, D. J., Arrébola, J., Backeljau, T., Balashov, I., Bank, R., Cameron, R., de Frias Martins, A. M., De Mattia, W., Dedov, I., Duda, M., Falkner, G., Falkner, M., Fehér, Z., Gargominy, O., Georgiev, D., Giusti, F., Gómez Moliner, B. J., Groh, K., Ibáñez, M., Kappes, H., Manganelli, G., Martínez-Ortí, A., Nardi, 
G., Neiber, M. T., Páll-Gergely, B., Parmakelis, A., Prié, V., Reischütz, A., Reischütz, P. L., Rowson, B., Rüetschi, J., Slapnik, R., Son, M., Štamol, V., Teixeira, D., Triantis, K., Vardinoyannis, K., von Proschwitz, T. \& Walther, F. (2019): European Red list of terrestrial molluscs. - IUCN: Cambridge, and Brussels.

https://portals.iucn.org/library/node/48439

Nicolai, A \& Ansart, A. (2017): Conservation at a slow pace: terrestrial gastropods facing fast-changing climate. - Conservation Physiology 5: cox007.

https://doi.org/10.1093/conphys/cox007

Poкryszko, B. M. (2001): Observations on seasonal dynamics of age-structure and reproduction of Pupilla muscorum L. (Gastropoda: Pulmonata: Pupillidae). - Folia Malacologica 9: 45-50. https://doi.org/10.12657/folmal.009.006

Proćкów, M., Drvotová, M., Juňič́ová, L. \& Kuźnik-Kowalska, E. (2013): Field and laboratory studies on the life-cycle, growth and feeding preference in the hairy snail Trochulus hispidus (L., 1758) (Gastropoda: Pulmonata: Hygromiidae). - Biologia 68: 131-141. https://doi.org/10.2478/s11756-012-0132-8

Proćкów, M. \& Kuźnik-Kowalska, E. (2016): Major fitness components in life history of euryoecious land snail Trochulus hispidus (Gastropoda: Hygromiidae). - Folia Malacologica 24: 179-184. http://dx.doi.org/10.12657/folmal.024.015

Riedel, A. \& Wiktor, A. (1974): Arionacea - Ślimaki krązałkowate i ślinikowate (Gastropoda: Stylommatophora). Fauna Polski 2. - PWN, Warszawa, 140 pp.

Seddon, M. B. \& de Frias Martins, A. M. (2011): Leptaxis simia. The IUCN Red list of threatened species 2011: e.T62289A12585324. https://dx.doi.org/10.2305/IUCN.UK.2011-1.RLTS.T62289A12585324.en.

Staikou, A. \& Lazaridou-Dimitriadou, M. (1990): Aspect of the life cycle, population dynamics, growth and secondary production of the snail Monacha cartusiana (Müller, 1774) (Gastropoda Pulmonata) in Greece. - Malacologia 31: 353-362. https://doi.org/10.1093/mollus/56.2.137

TAYLOR, J. W. (1916): Monograph of the land and freshwater Mollusca of the British Isles. - Taylor Brothers, Leeds, $160 \mathrm{pp}$.

Tomiyama, K. (1993): Growth and maturation pattern in the African giant snail Achatina fulica (Férussac) (Stylommatophora: Achatinidae). - Venus 52: 87-100.

Tompa, A. S. (1984): Land snails (Stylommatophora). Pp. 47-140. In: Tompa, A. S., Verdonk, N. H. \& Van Den BiggelaAr, J. A. M. (eds): The Mollusca 7. Reproduction. - Academic Press, Orlando, San Diego, San Francisco, New York, London, Sydney, Tokyo, Sao Paulo. https://doi.org/10.1016/B978-0-08-092659-9.50009-0

Triantis, K., Whittaker, R. J, Fernández-Palacios, J. M, \& Geist, D. J. (2016): Oceanic archipelagos: a perspective on the geodynamics and biogeography of the World's smallest biotic provinces. - Frontiers of Biogeography 8.2, e29605. http://dx.doi.org/10.21425/F5FBG29605

Wiктов, A. (1989): Limacoidea et Zonitoidea nuda - Ślimaki pomrowiokształtne (Gastropoda: Stylommatophora). Fauna Polski 12. - PWN, Warszawa, 208 pp.

Received May 2, 2021, accepted August 1, 2021, published November 19, 2021 